\title{
Visiting Friends and Relatives Distinguishing Between the two Groups: The Case of Hamilton, New Zealand
}

\author{
TIM LOCKYER and CHRIS RYAN
}

\begin{abstract}
Within tourism the term visiting 'friends and relatives' (VFR) is used with little distinction between the two components of 'friends' and 'relatives'. This paper examines the proposition that significant differences exist, and provides evidence of such differences derived from a survey of 763 respondents collected over a four month period. Although these differences are small, they indicate that those visiting friends are more likely to visit bars, night clubs and casinos than relatives; and relatives are more likely to visit gardens. Of particular importance is that specific patterns emerged as to attraction attendance and that age of visitor is perhaps more important than status as a 'friend' or a 'relative'. The data comprise both quantitative and qualitative forms. The former are analyzed by utilizing descriptive statistics, while the latter are analyzed using CATPAC software based on the principles of neural network analysis. A conceptual model is suggested to provide an insight into the phenomenon.
\end{abstract}

Keywords: visiting friends and relatives; market segmentation; leisure activities.

\section{Introduction}

While tourism arguably tends to be dominated by an industry catering to the needs of those seeking commercial accommodation, growing evidence has pointed to the importance of the 'Visiting Friends and Relatives' (VFR) sector. Certainly, various international visitor surveys and immigration landing cards in different countries have utilized the category to classify purpose of trip for many decades, thus permitting comparisons in flows of visitors motivated by this need with those travelling for purposes of holiday, business or other reasons. Nonetheless, in 1997 Seaton and Palmer felt able to comment 'Until the late 1980s VFR... tourism was one of the most neglected and under-researched categories in tourism analysis' (Seaton and Palmer 1997: 345). To some extent that apparent deficiency has been addressed. Indeed, Seaton and Palmer sought to assess patterns of spending of the VFR sector, its trip timing, destination choice and composition, among other factors, and concluded that expenditure levels were significant. They also noted, using five years of United Kingdom Tourism Survey data, that the VFR profile was heavily biased towards young, single people, or if older, couples who had children under the age of 15 years. They suggested that it also 'probably reflects the higher propensity of young people to have large friendship circles and visit them (Seaton and Palmer 1997: 354).
One of the earlier studies that concentrated upon the VFR sector was that of Jackson (1990). In an Australian study it was argued that in a world of increasing migratory patterns, VFR was not only a consequence but also a cause of such migrationthereby attributing to VFR an importance over and above simply travel for temporary periods of time. Jackson's work was published in the Journal of Tourism Studies and in 1995 that journal ran a special issue on the topic, many of which articles confirmed the importance and underestimation of the market segment. Morrison and O'Leary (1995) even entitled their article as 'The VFR Market: Desperately Seeking Respect' while Seaton and Palmer (1997: 345) offered as an explanation for the neglected state of this market that 'it had, no lobbying group championing it in the way that recreational and business tourism has'. In 2001 Lehto, Morrison and O'Leary conducted further examination of the 1997 In-Flight Survey of International Travellers that was conducted by the US Tourism Industries, Department of Commerce. Analysing a sample of 7,314 respondents they were able to distinguish between segments of the VFR market by age, country of trip origin and the degree to which VFR was estimated to be a primary or secondary travel motive based on factors such as usage of the commercial accommodation sector. Significant differences in expenditure patterns were found and the authors concluded that the VFR travel segment was marked by homogeneity and by a

\footnotetext{
TIM LOCKYER is Head of the Department of Tourism and Hospitality Management, The Waikato Management School, University of Waikato, Private Bag 3105, Hamilton, New Zealand. e-mail: lockyer@waikato.ac.nz CHRIS RYAN is Professor in the Department of Tourism Management, The Waikato Management School, University of Waikato, Private Bag 3105, Hamilton, New Zealand. e-mail: caryan@waikato.ac.nz
} 
comparative lack of seasonality when compared with other travel groups - both of which factors led them to suggest a need for further research in this group.

From an econometric perspective Turner and Witt (2001) attributed significant importance to the market in a study of inbound tourism flows to New Zealand from Australia, Japan, the United Kingdom and United States of America. They suggested that not only are these flows significant but they are, in the case of flows from the United Kingdom and Australia (and to a lesser but still statistically significant level in the case of USA), of growing importance. They also argued that indicators of consumer confidence such as new car registrations and the volume of retail sales are proxy predictive variables for the volume of such flows in that they indicate high levels of disposable income that make possible more VFR trips.

Such econometric studies advance the notion that VFR is an important component of tourism, but still tend to a view that VFR is homogeneous in its composition. Commentators have, however, sought to question this. Moscardo et al. (2000) proposed a model derived from the literature. Based upon accommodation usage, this model divides the market between those who visit both friends and relatives, those travellers who are accommodated exclusively by friends and relatives, and those whose accommodation needs are met either by some commercial accommodation or totally by that particular sector. The model was subsequently supported by an analysis of data collected on behalf of the Queensland Tourism Travel Corporation from 1995 to 1996. The dataset gave rise to four clusters entitled 'beach relaxation', 'inactive', 'active nature lovers' and finally 'active beach resort users'. These typologies were then compared

with various activities or features, which included those of visiting friends and relatives. It was found that approximately half of those that fell into the 'inactive' sector had, as their main reason for a trip, visiting friends and relatives.

However, from the perspective of analysing the visiting friends and relatives market, the data suffered from some difficulties. First, the dataset was raised primarily from those who used the commercial accommodation sector. Second, for much of the analysis there was no clear distinction made between those who were visiting friends, and those who visited relatives. Moscardo et al. (2000: 252) noted that in many studies, this 'VR vs. VF split is not considered', but unfortunately their own dataset did not permit a close analysis of this distinction. This was addressed by the work of Seaton and Tagg (1995) in an analysis of data derived from the Northern Ireland Tourist Board statistics for the period 1991 to 1993 . They concluded that there were specific differences in tourist behaviour which are concealed within an apparently homogeneous VFR category. For example, there was a predisposition within the visiting friends' category to be biased towards younger groups of people and thus, visitation to bars and clubs was more notable within this category. Arguably one problem of the analysis, seminal though it is for the purpose of this paper, is that it was based upon an interpretation of data collected for purposes other than the use which is reported. Nonetheless, the dataset suggests a number of possible postulation of a number of propositions that include:

a) Visiting relatives is primarily based around the presence of young children visiting grandparents, or between older groups of people. Consequently, behaviours to be exhibited by this group are more likely to be oriented toward trip activities that would include such things as visits to a zoo, to gardens and, if going out in the evening, potentially biased towards attending theatre shows.

b) On the other hand, the visiting friends classification may be biased towards those under the age of 25 , the trips maybe of shorter duration, and activities patronized would include those of going to bars, restaurants, nightclubs and discos.

c) Both groups may demonstrate, however, some similar levels of activity; for example, eating out in restaurants, going shopping and attending sporting events.

Seaton (1994: 318) set out a series of hypotheses about VFR trips and differential motives between travel involving 'friends' as against 'relatives' - for example, drawing attention to the role of special family occasions such as weddings and funerals, and that, on the other hand, friends trips are 'less structured by obligation and have a greater voluntaristic element.'

To some extent it can be argued that such trips are also culturally determined. For example Ioannides and Ioannides (2004) analysed trip patterns of American Jewry and concluded that Judaism as a cultural background was a determining influence on destination choice. Similarly, in a New Zealand context, Hall and Duval (2004) noted the importance of family ties in the travel patterns of Pacific Island residents in New Zealand.

To some extent these latter examples illustrate the greater fluidity of travel patterns and the role of new mobilities in the early $21^{\text {st }}$ century. Ryan and Trauer (2005) argued that the new patterns of international working create 'nomad tourists' who are global workers and tourists simultaneously as they create job histories based upon travel 
and work in different countries. Global patterns of friendships and family dispersal emerge, yet are nourished by communication through the Internet, and the ease of visiting, thereby giving new meanings to VFR tourism trips.

\section{The Purpose of the Research}

The purpose of the research was to elicit information to assess whether suggested relationships such as those, (a) to (c), listed above exist. The study differs from those cited above because it surveys not the visitors, but rather the residents of a New Zealand town who hosted visiting friends and relatives. Some inherent limitations in the research was that it was restricted to a recent past of 12 months and hence does not take into account the wider issues of nomad tourists. Moreover, the data apply primarily to pakeha (European) New Zealanders and thus does not address issues ,of migratory patterns as understood in the nonEuropean groups analysed by writers like Hall and Duval (2004). The data collected included sociodemographics of the respondents and their visitors plus information on the duration of stay, activities and places visited and similar matters with a view to assessing whether differences exist between 'friends' and 'relatives'. The data were collected in Hamilton, New Zealand, a university town with a population of 110,000 located about 90 minutes drive south of Auckland and about 45 minutes north of the adventure tourism location of Waitomo. Hamilton possesses a range of restaurants, a casino, and is geographically divided by the River Waikato. This is one of its tourist attractions and is used by a paddle boat steamer, the Waipa Delta. Other attractions include its zoo and gardens, which are both of international standard.

Respondents were primarily approached in locations like food courts in shopping malls and similar places. Convenience sampling was used. Survey participants were asked where they lived, whether any friends or relatives had come to stay in the past 12 months and, if so, into which category did they fall. The main part of the survey listed 18 attractions in Hamilton, New Zealand, and asked the participants to indicate if they had visited any of them with friends and relatives. The participants were also asked why they did not visit attractions in Hamilton using two openended questions.

The next section of the survey used a seven-point Likert scale. Each of the attractions in the previous section were listed again, and the participants were asked to rate their appeal using a scale from 1 ('Distinctly Unattractive') to 7 ('Very Attractive'). There was also a zero option indicating 'Have no opinion / do not feel able to rate / not applicable'. This approach permitted the researchers to discern the relationship between personal preferences of the hosts and actual attractions visited by friends and relatives. The final part of the survey sought socio-demographic data including age, income and gender. The surveys were administered over an extended period of about four months during the southern hemisphere summer period (starting January) and resulted in 763 usable responses.

\section{Sample Composition}

Table 1 provides details of the participants in the survey. A slightly higher number of females completed the survey than males. The largest proportion $(39.9 \%, \mathrm{n}=302)$ was aged between 21 and 30 years, with similar numbers earning between NZ\$20,000 and between NZ\$ 60,000 pa (approximately US\$12,600 to US\$ 37,800). This bias reflects the large numbers of young people resident in Hamilton because of the presence of two major educational institutions plus other tertiary sector establishments. Of the 763 respondents 558, or approximately 73 per cent, indicated that they had friends or relatives stay in the previous twelve months. Of these, 54 per cent were friends and 46 per cent were relatives.

\section{Table 1. Demographic Profile of the Sample of Hamilton} Residents (the hosts)

\begin{tabular}{|l|c|c|}
\hline Gender & Frequency & Percent \\
\hline Male & 331 & 43.6 \\
\hline Female & 429 & 56.4 \\
\hline Total & 760 & 100 \\
\hline Age & Frequency & Percent \\
\hline 20 or less & 126 & 16.6 \\
\hline 21 to 30 & 302 & 39.9 \\
\hline 31 to 40 & 128 & 16.8 \\
\hline 41 to 50 & 102 & 13.6 \\
\hline 51 to 60 & 62 & 8.3 \\
\hline 61 or older & 36 & .4 .8 \\
\hline Total & 756 & 100 \\
\hline Income & Frequency & Percent \\
\hline Less than $\$ 20,000$ & 166 & 23.8 \\
\hline$\$ 20,001$ to $\$ 40,000$ & 164 & 23.6. \\
\hline$\$ 40,001$ to $\$ 60,000$ & 136 & 18.8 \\
\hline$\$ 60,001$ to $\$ 80,000$ & 117 & 16.4 \\
\hline$\$ 80,001$ to $\$ 100.000$ & 69 & 9.0 \\
\hline More than $\$ 100,000$ & 64 & 8.4 \\
\hline Total & 716 & 100 \\
\hline
\end{tabular}

Note: some respondents did not indicate their gender

Table 2 provides details of the ages, gender and group size of the visiting friends and relatives as provided by the hosts. The categorization of a visitor as a 'friend' or 'relative' was self selected by the respondents; that is, they selected a visit made by either a 'friend' or a 'relative' about which they provided data. As is evident from the table, the friends 
Table 2. Characteristics of Friends and Relatives who visited the Hosts

\begin{tabular}{|}
\hline Ages, Gender and Group Size of Visiting Friends and \\
\hline Age & \multicolumn{2}{|c|}{ Friends } & \multicolumn{2}{c|}{ Relatives } \\
\hline 20 or less & Frequency & Percent & Frequency & Percent \\
\hline 21 to 30 & 60 & 20.2 & 36 & 14.3 \\
\hline 31 to 40 & 159 & 53.5 & 51 & 20.2 \\
\hline 41 to 50 & 28 & 12.1 & 53 & 21.0 \\
\hline 51 to 60 & 10 & 9.4 & 46 & 18.3 \\
\hline 61 or older & 4 & 1.3 & 37 & 14.7 \\
\hline Total & 297 & 100.0 & 29 & 11.5 \\
\hline
\end{tabular}

Gender and Group Size of Visiting Friends and

\begin{tabular}{|l|c|l|c|c|}
\hline $\begin{array}{c}\text { Number in } \\
\text { Group }\end{array}$ & \multicolumn{2}{|c|}{ Friends } & \multicolumn{2}{c|}{ Relatives } \\
\hline 0 & 30.0 & 31.7 & 272 & 20.5 \\
\hline 1 & 42.2 & 44.6 & 53.5 & 59.8 \\
\hline 2 & 14.2 & 14.2 & 13.0 & 11.8 \\
\hline 3 & 7.6 & 5.6 & 4.7 & 3.5 \\
\hline 4 & 3.0 & 2.3 & 1.2 & 2.8 \\
\hline 5 & 1.3 & .3 & .4 & .4 \\
\hline 6 & 1.0 & .7 & 0 & 1.2 \\
\hline 7 & .7 & .3 & 0 & 0 \\
\hline Total & 100.0 & 100.0 & 100.0 & 100.0 \\
\hline
\end{tabular}

are younger than relatives with 53.5 per cent aged 21 to 30 years old compared to relatives, which have 20.2 per cent in the same age category. The relatives are older with 14.7 per cent aged between 51 to 60 years of age and 3.4 per cent in the same category for friends $\left(X^{2}=100.6, d f=5, p<0.001\right)$. The second part of Table 2 looks at the gender and group sizes of visiting friends and relatives. For each group there was little difference between genders and the main difference is that friends who visited their hosts tended to a slightly larger size of group when compared to visiting relatives (2.3 compared to 2.1 people) but not at statistically significant levels $(t=1.19, \mathrm{p}=0.235)$.

\section{Research Results}

\section{Visitation Patterns}

As already noted, participants were given a list of 18 attractions and asked to indicate if they had taken their visiting friends or relatives to these attractions. Many respondents indicated that multiple attractions were visited. Table 3 presents the findings for this part of the survey. The two columns to which particular attention should be given are those headed 'Friends Common Size' and 'Relatives Common Size'. These two columns were calculated by expressing the number of trips made to an attraction as a - percentage of all trips to all attractions, thus producing a 'market share index'. The number in the'[ 1 ' square brackets is the descending order of importance (as measured by numbers of trips) for each of the groups of 'visiting friends' and 'visiting relatives' with the data presented in the order of importance for the classification of 'visiting friends'. Table 3

Table 3. Comparative Common Size Analysis between the attractions Visited by Friends and Relatives

\begin{tabular}{|c|c|c|c|c|c|}
\hline & $\begin{array}{c}\text { Number } \\
\text { of Friends taken } \\
\text { to attraction }\end{array}$ & $\frac{\text { Friends }}{\text { Common Size }}$ & $\begin{array}{c}\text { Number } \\
\text { of Relatives taken } \\
\text { to attraction }\end{array}$ & Relatives Common Size & Total \\
\hline Waipa Delta Paddle Steamer & 511 & [1] $29.71 \%$ & 200 & [1] $18.13 \%$ & 711 \\
\hline Restaurants & 170 & [2] $9.88 \%$ & 154 & [2] $13.96 \%$ & 324 \\
\hline Night clubs & 147 & [3] $8.55 \%$ & 50 & [9] $4.53 \%$ & 197 \\
\hline Bars & 139 & [4] $8.08 \%$ & 66 & [7] $5.98 \%$ & 205 \\
\hline Main Hamilton Shopping Centre & 138 & [5] $8.02 \%$ & 134 & [3] $12.15 \%$ & 272 \\
\hline Cinemas in Hamilton & 121 & [6] $7.02 \%$ & 79 & [5] $7.16 \%$ & 200 \\
\hline Ragland & 101 & [7] $5.87 \%$ & 73 & [6] $6.62 \%$ & 174 \\
\hline Hamilton Gardens & 99 & [8] $5.76 \%$ & 99 & [4] $8.98 \%$ & 198 \\
\hline Hamilton Casino & 97 & [9] $5.64 \%$ & 59 & {$[8] 5.35 \%$} & 156 \\
\hline Hamilton Zoo & 45 & [10] $2.62 \%$ & 48 & {$[10] 4.35 \%$} & 93 \\
\hline $\begin{array}{l}\text { Organized Sports Attractions or } \\
\text { Games }\end{array}$ & 39 & {$[11] 2.27 \%$} & 31 & {$[12] 2.81 \%$} & 70 \\
\hline Swimming Pool (Water World) & 38 & [12] $2.21 \%$ & 34 & [11] $3.08 \%$ & 72 \\
\hline Waikato Museum & 26 & [13] $1.51 \%$ & 24 & [13] $2.18 \%$ & 50 \\
\hline Founders Theatre & 24 & {$[14] 1.40 \%$} & 20 & {$[14] 1.81 \%$} & 44 \\
\hline Candyland & 11 & [15] $0.64 \%$ & 19 & {$[15] 1.72 \%$} & 30 \\
\hline Donovan's Chocolates & 6 & [16] $0.35 \%$ & 6 & [16] $0.54 \%$ & 12 \\
\hline Woodlands Homestead & 5 & [17] $0.29 \%$ & 5 & [17] $0.45 \%$ & 10 \\
\hline \multirow[t]{2}{*}{ Robinson's Sports Museum } & 3 & {$[18] 0.17 \%$} & 2 & {$[18] 0.18 \%$} & 5 \\
\hline & 1720 & $100.00 \%$ & 1103 & $100.00 \%$ & \\
\hline
\end{tabular}


shows that the Waipa Delta Paddle Steamer was the most visited site for 'visiting friends' (29.71 per cent) and 'visiting relatives' (18.13 per cent). It is also evident that 'visiting friends' patronized night clubs (8.55 per cent) and bars (8.08 per cent) more than 'visiting relatives' (4.53 per cent and 5.98 per cent respectively), while 'visiting relatives' patronized the Hamilton Gardens (8.98 per cent), Hamilton Zoo (4.35 per cent), restaurants (13.96 per cent) and Hamilton shops (12.15 per cent) noticeably more than hosted friends (5.75 per cent, 2.62 per cent, 9.88 per cent, 8.02 per cent respectfully). Other attractions showed little difference.

The analysis in Table 4 separates each attraction visited by the hosted friends and relatives and divides the sample by those who were over and under the age of 40 years. This is an arbitrary division, but does act as a proxy for different life stages in terms of the probability of the presence of young children. Some supporting data exist for this division; for example 70 per cent of the groups with children under 16 years of age existed in the 'visiting relatives' group, which also had the higher mean age. In Table 4 the largest percentage of the given age groups for each case given is shown in bold font. Visitation patterns are affected by at least four variables; a) the nature of the attraction, b) whether the visitor is a 'friend' or a 'relative', c) the age of the hosted relative or friend and d) the age of the host. For example, it initially appeared that the Waipa Delta Paddle Steamer is favoured by hosts over 40 years of age, and 'visiting relatives' more than 'visiting friends' as shown in Table 4. However, closer examination of the data revealed no statistical significant linkage between whether the visitor was a relative or a friend and in this specific case the conclusion was drawn that of the three variables examined, age of host and the nature of the attraction were the prime determinant in selection of this specific activity. It was also found that the age of the host was a key determinant of the pattern of usage of nightclubs by friends and relatives. Indeed, for the most part a strong correlation exists between the age of the host and the age of the visitor independent of whether the visitor is a 'visiting friend' or a 'visiting relative' in determining activity, other than in the case of organized sports.

Another issue is whether patterns of patronage help determine groupings of attractions or activities. For example, do those who visit the Hamilton Gardens also visit the Hamilton Zoo? Table 5 presents such an analysis based upon coefficients of correlation of visitation rates. In the table, those correlations greater than 0.3 are shown in bold print. The results indicated that, for example, those visiting 'Night Clubs' have an apparent pre-disposition to visit the 'Hamilton Casino' and 'Bars', but do not visit the 'Swimming Pool', the 'Hamilton Gardens' or the 'Waipa Delta'. Those
Table 4. Attractions Visited by Friends and Relates by Age

\begin{tabular}{|c|c|c|c|c|c|}
\hline \multirow{2}{*}{ Attrac-tion } & \multirow{2}{*}{$\begin{array}{l}\text { Type of } \\
\text { Visitor }\end{array}$} & \multirow{2}{*}{$\begin{array}{l}\text { Visitor / } \\
\text { Resident }\end{array}$} & \multicolumn{2}{|c|}{ Age } & \multirow{2}{*}{$\begin{array}{c}\text { Pearson } \\
\text { Chi- } \\
\text { Square }\end{array}$} \\
\hline & & & $=<40$ & $>40$ & \\
\hline \multirow{4}{*}{$\begin{array}{l}\text { Waipa } \\
\text { Delta }\end{array}$} & \multirow{2}{*}{ Friends } & Age of Visitor & $5.9 \%$ & $19 \%$ & $8.75^{* *}$ \\
\hline & & Age of Resident & $7.1 \%$ & $1.0 \%$ & 0.48 \\
\hline & \multirow[b]{2}{*}{ Relatives } & Age of Visitor & $8.6 \%$ & $9.8 \%$ & .117 \\
\hline & & Age of Resident & $3.3 \%$ & $17.8 \%$ & $15.36^{* *}$ \\
\hline \multirow{4}{*}{$\begin{array}{l}\text { Restau- } \\
\text { rants }\end{array}$} & \multirow{2}{*}{ Friends } & Age of Visitor & $54.3 \%$ & $67 \%$ & 2.23 \\
\hline & & Age of Resident & $54.6 \%$ & $66.0 \%$ & 2.21 \\
\hline & \multirow{2}{*}{ Relatives } & Age of Visitor & $57.8 \%$ & $65.8 \%$ & 2.26 \\
\hline & & Age of Resident & $64.0 \%$ & $55.0 \%$ & 2.72 \\
\hline \multirow{4}{*}{$\begin{array}{l}\text { Night } \\
\text { clubs }\end{array}$} & \multirow{2}{*}{ Friends } & Age of Visitor & $55.3 \%$ & $7.1 \%$ & $33.47 * *$ \\
\hline & & Age of Resident & $55.9 \%$ & $10.0 \%$ & $35.28 * *$ \\
\hline & \multirow{2}{*}{ Relatives } & Age of Visitor & $30.7 \%$ & $6.2 \%$ & $24.51 * *$ \\
\hline & & Age of Resident & $25.8 \%$ & $9.9 \%$ & $10.64 * *$ \\
\hline \multirow{4}{*}{ Bars } & \multirow[b]{2}{*}{ Friends } & Age of Visitor & $51.3 \%$ & $14.3 \%$ & 19.961, \\
\hline & & Age of Resident & $52.4 \%$ & $12.0 \%$ & $27.42 * *$ \\
\hline & \multirow{2}{*}{ Relatives } & Age of Visitor & $36.4 \%$ & $13.4 \%$ & $18.19 * *$ \\
\hline & & Age of Resident & $32.5 \%$ & $16.8 \%$ & $8.49^{*}$ \\
\hline \multirow{4}{*}{$\begin{array}{l}\text { Hamilton } \\
\text { Shops }\end{array}$} & \multirow{2}{*}{ Friends } & Age of Visitor & $45.1 \%$ & $47.6 \%$ & 0.09 \\
\hline & & Age of Resident & $46.0 \%$ & $42.0 \%$ & 0.27 \\
\hline & \multirow{2}{*}{ Relatives } & Age of Visitor & 56.4 & 49.9 & 1.34 \\
\hline & & Age of Resident & $52.3 \%$ & $54.5 \%$ & 0.11 \\
\hline \multirow{4}{*}{$\begin{array}{l}\text { Cinemas in } \\
\text { Hamilton }\end{array}$} & \multirow{2}{*}{ Friends } & Age of Visitor & $42.1 \%$ & $21.4 \%$ & $7.07 * *$ \\
\hline & & Age of Resident & $41.7 \%$ & $32.0 \%$ & 1.62 . \\
\hline & \multirow{2}{*}{ Relatives } & Age of Visitor & $41.4 \%$ & $18.7 \%$ & $14.87 * *$ \\
\hline & & Age of Resident & $33.1 \%$ & $27.7 \%$ & 0.82 \\
\hline & & Age of Visitor & $29.0 \%$ & $52.4 \%$ & $8.99 * *$ \\
\hline Hamilton & Friends & Age of Resident & $28.6 \%$ & $52.0 \%$ & $10.45^{* *}$ \\
\hline Gardens & Relatives & Age of Visitor & $35.7 \%$ & $43.7 \%$ & 1.68 \\
\hline & Keratives & Age of Resident & $38.4 \%$ & $49.5 \%$ & 0.04 \\
\hline & & Age of Visitor & $31.8 \%$ & $30.9 \%$ & 0.01 \\
\hline Hamilton & Friends & Age of Resident & 56.6 & $20.0 \%$ & $3.84 *$ \\
\hline Casino & & Age of Visitor & $22.9 \%$ & $24.1 \%$ & 0.05 \\
\hline & Relatives & Age of Resident & $25.2 \%$ & $20.8 \%$ & 0.65 \\
\hline & Friends & Age of Visitor & $14.9 \%$ & $14.3 \%$ & 0.01 \\
\hline & prienas & Age of Resident & $14.3 \%$ & $16.0 \%$ & 0.09 \\
\hline Zoo & Relat & Age of Visitor & $20.0 \%$ & $17.9 \%$ & 0.18 \\
\hline & Heratives & Age of Resident & $19.9 \%$ & $16.8 \%$ & 0.37 \\
\hline & Friends & Age of Visitor & $12.5 \%$ & $11.9 \%$ & 0.01 \\
\hline Organized & & Age of Resident & $11.5 \%$ & $20.0 \%$ & 167 \\
\hline Sports & & Age of Visitor & $13.6 \%$ & $10.7 \%$ & 0.47 \\
\hline & Relatives & Age of Resident & $13.9 \%$ & $9.9 \%$ & 0.90 \\
\hline & Frien & Age of Visitor & $12.5 \%$ & $9.5 \%$ & 0.31 \\
\hline Swimming & Frienas & Age of Resident & $12.3 \%$ & $14.0 \%$ & 0.11 \\
\hline Pool & $\mathrm{R}$ & Age of Visitor & $17.8 \%$ & $8.0 \%$, & , 5.14* \\
\hline & peratuve & Age of Resident & $12.6 \%$ & $14.8 \%$ & 0.27 \\
\hline
\end{tabular}


Table 5. Cross Correlation Matrices of Attractions Visited

\begin{tabular}{|c|c|c|c|c|c|c|c|c|c|c|c|}
\hline & $\begin{array}{c}\text { Hamilton } \\
\text { Casino }\end{array}$ & $\begin{array}{c}\text { Swimmin } \\
\text { Pool }\end{array}$ & \begin{tabular}{|l|} 
Waipa \\
Delta \\
\end{tabular} & Bars & \begin{tabular}{|c|} 
Hamilton \\
Gardens
\end{tabular} & \begin{tabular}{|c|} 
Hamilton \\
Zoo
\end{tabular} & $\begin{array}{c}\text { Organised } \\
\text { Sports }\end{array}$ & $\begin{array}{l}\text { Night } \\
\text { Clubs }\end{array}$ & Restaurants & $\begin{array}{l}\text { Cinemas } \\
\text { Hamilton }\end{array}$ & $\begin{array}{c}\text { Hamilton } \\
\text { Shops }\end{array}$ \\
\hline Hamilton Casinos & 1 & & & & & & & & & & \\
\hline Swimming Pool & 0.001 & 1 & & & & & & & & & \\
\hline Waipa Delta & 0.154 & 0.083 & 1 & & & & & & & & \\
\hline Bars & 0.315 & 0.071 & 0.051 & 1 & & & & & & & \\
\hline $\begin{array}{l}\text { Hamilton } \\
\text { Gardens }\end{array}$ & 0.193 & 0.181 & 0.207 & 0.050 & 1 & & & & & & \\
\hline Hamilton Zoo & 0.159 & 0.247 & 0.104 & 0.050 & 0.370 & 1 & & & & & \\
\hline Organised Sports & 0.075 & 0.113 & 0.051 & 0.161 & 0.089 & 0.131 & 1 & & & & \\
\hline Night Club & 0.308 & 0.045 & -0.031 & 0.580 & 0.024 & 0.064 & 0.146 & 1 & & & \\
\hline Restaurant & 0.276 & 0.093 & 0.193 & 0.328 & 0.307 & 0.174 & 0.088 & 0.251 & 1 & & \\
\hline $\begin{array}{l}\text { Cinemas } \\
\text { Hamilton }\end{array}$ & 0.228 & 0.271 & 0.107 & 0.254 & 0.266 & 0.241 & 0.191 & 0.309 & 0.337 & 1 & \\
\hline Hamilton. Shops & 0.310 & 0.183 & 0.171 & 0.238 & 0.366 & 0.254 & 0.121 & 0.230 & 0.452 & 0.388 & 1 \\
\hline
\end{tabular}

who visited the 'Waipa Delta' also visited the 'Gardens' and 'Restaurants'.

\section{Reasons for Visits}

The next part of the survey asked the participants, 'Considering the places that you visited, could you please say why you visited them'? This was an open-ended question and to analyse the comments the software package, CATPAC, was used. This permits the drawing of perceptual maps. Like many such tools it requires the researcher to engage in a series of interpretive acts with reference to the text. For example, a standardization of the text with reference to the use of singular or plural versions of nouns, the direction of positive and negative statements, the use of personal pronouns need to be addressed and the emergence of categories, of statements is thus developed. The advantage of such software is that it permits co-researchers to assess the credibility of interpretations by leaving a 'footpath' of files to be examined. CATPAC also requires a determination of word counts as the base unit of interpretation to optimise the clarity of findings that emerge from the textual analysis. Also after some experimentation the clearest representation of the underlying meaning emerged with a small scan window of 5 words. This means that the programme first reads words 1 through 5 , and then moves to words 2 through 6 and so forth in determining spatial positions. The reason for the small scan window was that in examining the participant's responses, they tended to use quite short sentences. The findings are presented in the form of a spatial map and Figures 1 and 2 show a simplified version of the final maps with reference to motivations for use of the attractions and facilities by friends and relatives respectively. In such maps it is the spatial relationship that indicates the degree of correlation. Short labels are used to demonstrate the relationships.
Figure 1. for 'visiting friends' indicates a relationship between 'Enjoy' and 'Entertainment' with other groupings existing between 'Drink', 'Shopping', 'Eat' and a group comprising 'Friends', 'Show', 'Good' and 'Fun'. Figure 2, the map for 'visiting relatives', shows a different pattern of motives, attractions and clusters. A loose relationship exists between 'Gardens', 'Children' and 'Visit', with another grouping of 'Fun' and 'Children' along with a weak connection to 'Dinner'. The final relationships include 'Good', 'Family' and 'Entertainment'. In each of the groupings for relatives the words 'Children', 'Kids' and 'Family' appear. One interpretation of these maps implies that the 'visiting friends' indicate motives of excitement and fun as reasons for making visits while the 'visiting relatives' motives are oriented towards family relationships and an orientation towards the use of facilities that appeal to family outings with young children or older relatives.

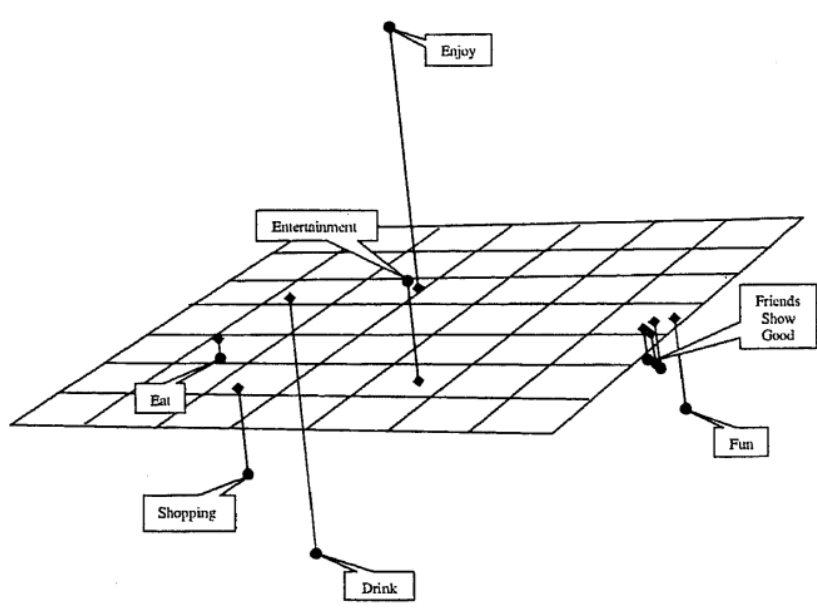

Figure 1. Spatial Map of Friends Reason for Visiting Attraction 
Visiting Friends and Relatives - the Case of Hamilton: T. Lockyer and C. Ryan

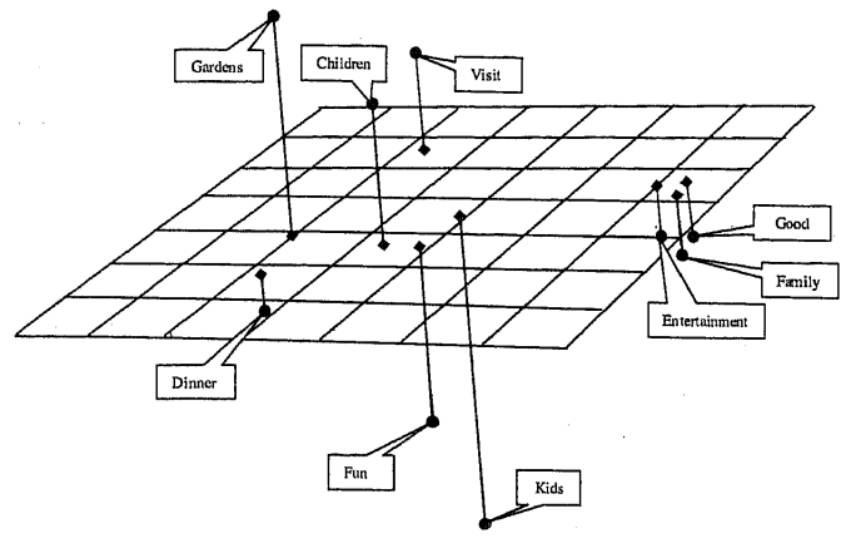

Figure 2. Spatial Map of Relatives Reason for Visiting Attraction

\section{Satisfaction with Attraction and Visiting with Friend or Relative}

The next part of the survey listed the same attractions shown in Table 3 and asked, using a seven point scale (as previously noted, $1=$ 'Distinctly Unattractive' to $7=$ 'Very Attractive'), how attractive the facilities were to the respondent (the host). This approach permitted the researchers to assess if the host's view of the attractiveness of a facility influenced actual visit behaviour with their friend or relative. Table 6 illustrates the comparison between the views of residents separated by the type of visitor hosted, (friend or relative) in descending mean order of ranking of attractiveness of activities. Once again although there are some similarities, there are also some differences. For friends the top rated item is Raglan (mean 5.66). This is a coastal recreation area about 30 minutes by car from Hamilton, well known particularly for its surfing), while for those hosting relatives Hamilton Gardens is rated the most highly (mean 5.83). For those hosting friends, Hamilton Gardens is rated a lot lower (mean 5.22). Restaurants are rated second by those hosting friends (mean 5.64) but are higher by those hosting relatives (mean 5.82). Another attraction of particular interest is the Waipa Delta, which is rated a lot higher by residents who hosted 'visiting relatives' (mean 4.93) than by those who hosted 'visiting friends' (3.94).

Subsequently, data comprising three variables, namely (1) hosts' assessment of the attractiveness of an activity, (2) whether they hosted friends or relatives and (3) whether they actually visited the attraction were analysed to better understand the relationship between visiting an attraction and how attractive it is to local residents. The results are illustrated in Table 7 that contains two main sections. The first, on the left of the vertical double line, relates to hosting 'visiting friends', while on the right the figures relate to 'visiting relatives'. The column headed 'Yes Mean' under
Table 6. Comparison between Views of Residents of Attractiveness of Activities

\begin{tabular}{|c|c|c|c|c|}
\hline \multicolumn{2}{|c|}{$\begin{array}{c}\text { View of Residents with Friends } \\
\text { Visiting }\end{array}$} & \multicolumn{3}{|c|}{$\begin{array}{c}\text { View of Residents with } \\
\text { Relatives Visiting } \\
\end{array}$} \\
\hline \multicolumn{5}{|c|}{ Std. } \\
\hline & & Hamilton & & \\
\hline Raglan & 5.66 & 1.42 Gar dens & 5.83 & 1.20 \\
\hline $\begin{array}{l}\text { Restaurants } \\
\text { Main Hamilton }\end{array}$ & 5.64 & 1.17 Restaurants & 5.82 & 1.10 \\
\hline Shopping Centre & 5.34 & $\begin{array}{l}\text { 1.28 Raglan } \\
\text { Main Hamilton }\end{array}$ & 5.69 & 1.29 \\
\hline $\begin{array}{l}\text { Bars } \\
\text { Cinemas in }\end{array}$ & 5.27 & $\begin{array}{l}\text { 1.49 Shopping Centre } \\
\text { Cinemas in }\end{array}$ & 5.51 & 1.24 \\
\hline $\begin{array}{l}\text { Hamilton } \\
\text { Hamilton }\end{array}$ & 5.24 & $\begin{array}{l}\text { 1.24 Hamilton } \\
\text { Organised Sports }\end{array}$ & 5.27 & 1.17 \\
\hline Gardens & 5.22 & $\begin{array}{l}1.60 \text { Attractions } \\
\text { Waipa Delta }\end{array}$ & 5.07 & 1.41 \\
\hline $\begin{array}{l}\text { Night clubs } \\
\text { Organised } \\
\text { Sports }\end{array}$ & 5.20 & 1.72 Paddle Steamer & 4.95 & 1.45 \\
\hline Attractions & 5.13 & 1.53 Bars & 4.89 & 1.67 \\
\hline Hamilton Casino & 5.01 & 1.61 Hamilton Zoo & 4.84 & 1.48 \\
\hline $\begin{array}{l}\text { Hamilton Zoo } \\
\text { Swimming pool }\end{array}$ & 4.55 & 1.55 Hamilton Casino & 4.77 & 1.67 \\
\hline $\begin{array}{l}\text { (Water World) } \\
\text { Waikato }\end{array}$ & 4.33 & $\begin{array}{l}1.55 \text { Night clubs } \\
\text { Swimming pool }\end{array}$ & 4.63 & 1.94 \\
\hline $\begin{array}{l}\text { Museum } \\
\text { Waipa Delta }\end{array}$ & 3.94 & 1.53 (Water World) & 4.59 & 1.51 \\
\hline $\begin{array}{l}\text { Paddle Steamer } \\
\text { Founders }\end{array}$ & 3.94 & 1.56 Waikato Museum & 4.49 & 1.55 \\
\hline Theatre & 3.91 & $\begin{array}{l}1.51 \text { Founders Theatre } \\
\text { Woodlands }\end{array}$ & 4.33 & 1.57 \\
\hline $\begin{array}{l}\text { Candyland } \\
\text { Donovan's }\end{array}$ & 3.78 & 1.58 Homestead & 4.27 & 1.76 \\
\hline Chocolates & 3.64 & 1.59 Candyland & 4.18 & 1.47 \\
\hline Woodlands & & Don.ovan's & & \\
\hline Homestead & 3.37 & 1.65 Chocolates & 3.83 & 1.41 \\
\hline Robinson's & & Robinson's Sports & & \\
\hline Sports Museum & 3.17 & 1.54 Museum & 3.51 & 1.56 \\
\hline
\end{tabular}

'Friend' indicates that the attraction was visited with the visiting friend, with the mean reporting the attractiveness of the attraction for the host, while the column headed 'No Mean' indicates that the attraction was not visited with the visiting friend, with the mean again reporting the attractiveness of the attraction for the host. Likewise, under the heading Relatives, again there are two headings: 'Yes Mean' and 'No Mean' indicating whether they were visited with relatives or not, and the attractiveness mean. In considering Table 7 it must be noted that only those attractions that were visited by more than 40 persons in the survey are included.

What appears to emerge from the table is a correlation between the hosts' views of an attraction and if it was visited 


\section{Table 7. Hosts' Rating of Activity 'Attractiveness' by}

a) Nature of guest hosted (friend or relative), and

b) Whether the activity was indulged in (yes or no).

\begin{tabular}{lccc|ccc}
\hline & \multicolumn{3}{c|}{ Hosted Friends } & \multicolumn{3}{|c}{ Hosted Relatives } \\
\hline & Yes & No & t- & Yes & No & t- \\
& Mean & Mean & value & Mean & Mean & value \\
Hamilton Gardens & 5.89 & 4.83 & $5.35^{* *}$ & 6.28 & 5.50 & $5.34^{* *}$ \\
Hamilton Zoo & 5.44 & 4.33 & $4.52^{* *}$ & 5.46 & 4.64 & $335^{* *}$ \\
Cinemas in Hamilton & 5.49 & 5.05 & $2.90^{* *}$ & 5.47 & 5.15 & 1.95 \\
Founders Theatre & 4.68 & 3.81 & $2.59^{*}$ & 5.00 & 4.24 & $2.77^{*}$ \\
Waipa Delta Paddle & & & & & & \\
Steamer & 5.65 & 3.73 & $6.06^{* *}$ & 6.09 & 4.80 & $6.59^{* *}$ \\
Organised Sports & & & & & & \\
Attractions or Games & 6.09 & 4.96 & $4.10^{* *}$ & 5.87 & 4.92 & $4.28^{* *}$ \\
Night clubs & 5.89 & 4.26 & $8.39^{* *}$ & 5.72 & 4.27 & $5.50^{* *}$ \\
Restaurants & 5.81 & 5.39 & $2.95^{* *}$ & 6.05 & 5.43 & $4.16^{* *}$ \\
Raglan & 6.22 & 5.33 & $5 A 4^{* *}$ & 6.21 & 5.44 & $4.80^{* *}$ \\
Waikato Museum & 5.32 & 3.78 & $6.22^{* *}$ & 5.26 & 4.38 & $3.13^{* *}$ \\
Hamilton Casino & 5.66 & 4.58 & $5.53^{* *}$ & 5.66 & 4.39 & $5.98^{* *}$ \\
Main Hamilton & & & & & & \\
Shopping Centre & 5.56 & 5.14 & $2.74 *$ & 5.89 & 5.03 & $5.38^{* *}$ \\
Bars & 5.78 & 4.69 & $6.11^{* *}$ & 5.73 & 4.46 & $6.39^{* *}$ \\
Swimming pool & 5.11 & 4.19 & $3.35^{* *}$ & 5.76 & 4.34 & $6.71^{* *}$ \\
\hline Nwimm & & & & &
\end{tabular}

Note: * t-test two tail probability $<0.05$; ** t-test two-tail probability $<0.01$.

Note: * t-test two tail probability $<0.05 ; * *$ t-test two-tail probability $<0.01$.

by their friends or relatives. Simply put, if the host considers an activity or site attractive, then the visiting friend or relative is more likely to be taken to that site.

\section{Discussion}

This- paper reports results derived from a sample of residents of New Zealand who had hosted 'visiting friends' and 'visiting relatives'. The research sought to examine whether there were differences in the activities undertaken by hosts and their guests based upon the nature of the guest. The datasets indicate that, at least in Hamilton, New Zealand, some important differences exist between the activities and places patronized by hosted 'friends' as against hosted 'relatives'. The paper earlier suggested that differences might well exist between hosted friends and hosted relatives in that, for example, 'visiting relatives' might be more likely to visit the Hamilton Zoo rather than go to a bar. It was thought such differences might be explained by age and life-style profiles. Indeed, in this sample, differences between the two groupings of visitors were found with respect to age, but not to gender (see Tables 2). It was found that age has a significant role to play; for example, younger people tend to have higher usage rates of bars and night clubs than their older counterparts; implying therefore that age is a greater determinant of such patronage than the status of being a 'friend' or 'relative'. The age of the host is also a factor. Patronage rates are also influenced by the degrees of attractiveness attributed to a place or activity by hosts. This set of preferences seems to be place specific. An analysis that provided correlations based on patronage of attractions/ activities provided readily interpretable groupings of sites, but there was little evidence that these translated into clear groupings of attractions to be visited by hosts and their 'visiting friends' and 'visiting relatives'. For example, while the historical paddle steamer Waipa Delta clustered with the museum, patronage of the former did not imply 'automatic' patronage of the latter. Obviously, a boat trip down a river has connotations beyond the historic, and thus the boat trip also clustered with the Hamilton Gardens on, arguably, an aesthetic premise.

The results support the contentions and findings made by previous researchers that the VFR market is far from homogeneous. Indeed, the scenario seems even more complex than that envisaged by previous data analysis of the VFR market. In part, that is perhaps because the analyses have been derived from sets of statistics designed for the general monitoring of markets and based upon surveys of visitors as distinct from the approach adopted in this paper, which was to survey the resident hosts. This latter approach permits a comparison of both host and guest preferences, sociodemographics and activity preferences. A proposed conceptual model is provided in Figure 3 . This provides

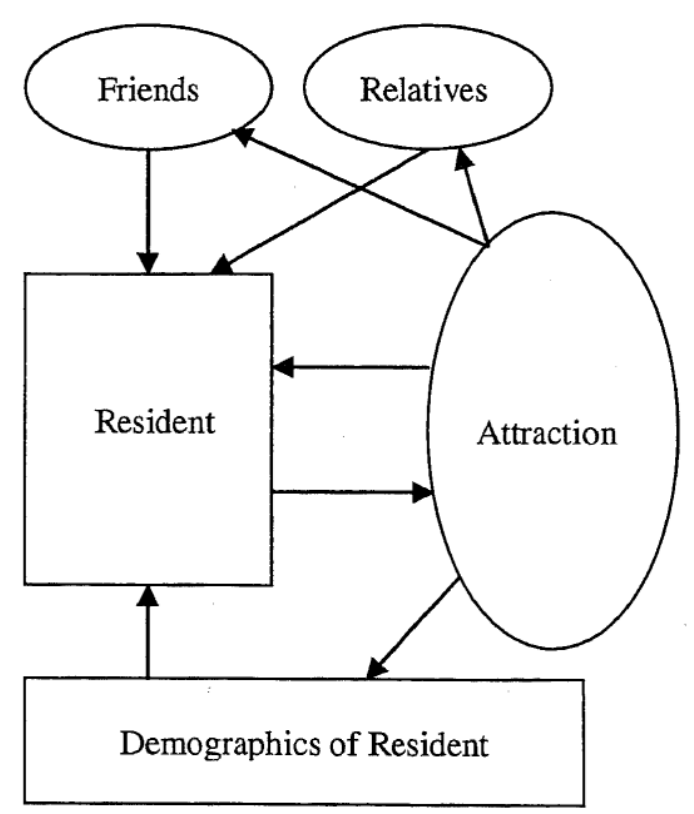

Figure 3. Conceptual Model of Visiting friends and relatives 
centrality to the relationship between the resident and the local attraction. The nature of the attraction and its appeal to the resident (based in part upon socio-demographics such as age, gender and life-stage, and upon psychographics) induces a visit by the resident. That experience of that attraction by the host in turn becomes a determinant of recommendation on the part of hosts as to what activities their visiting friends and relatives may find to be of pleasure and interest. The socio-demographics of both hosts and their visiting friends and relatives also become a determinant of patronage. In short, differences between visiting friends and relatives are discernible but they are filtered through these other key components of age, gender, interest and past patronage of attractions by local people.

One clear, albeit not new observation, that emerges from the study is the importance of the commercial sector not under-estimating the importance of the local host population. In major urban conurbations where significant flows of visitors will be derived from the VFR sector, there seems to be value in sustaining relationships between attractions and local population. This requires attractions to generate new stories and investment to create repeat visitation by local populations. One means is by establishing local support groups as demonstrated by the Hamilton Zoo's 'Friends of the Zoo' programme and its volunteer programme. Involving local people whether by volunteer action, discounted entry fees, producing stories for local news media, offering meeting space for local clubs and sponsorship of local events may be a cost effective way of increasing visitation rates through tapping into the VFR market. Failure to undertake such ventures may save costs and time in the short run, but at the expense of not increasing revenues in the longer term, as in turn the visiting friends and relatives might not recommend an attraction to their friends and relatives.

\section{Conclusion}

From a conceptual perspective the results of this study indicate the importance of utilizing research instruments specific to the issue of VFR in addition to re-interpreting datasets derived from statistics such as domestic or international visitor surveys. Such surveys are often used to first assess the effectiveness and justify the existence of National Tourism Organization marketing initiatives and second to permit forecasting of future tourist flows. It is suggested that by their nature such datasets cannot capture the nuances uncovered by surveys oriented towards residents and the nature of their hosting. The authors would wish to encourage similar research in other locations because while of interest, these finding are contextualized within a specific place and thus may have limited generalizability. It should also be noted that the dataset was based upon convenience sampling and thereby potentially contains limitations, while generally it is also thought that a need exists for more detailed qualitative research to better understand the 'experience' gained from activities as distinct from this study method which basically identifies activities without really exploring their contribution to sustaining relationships between friends and families. Finally, therefore, it is suggested that the nature of VFR markets is more complex than normally assumed and would reward closer examination by researchers.

\section{Note}

The authors' names are simply in alphabetical order and the project was shared equally between the researchers.

\section{References}

HALL, C. M. and DUVAL, D. T. (2004). Linking Diasporas and Tourism - Transnational Mobilities of Pacific Islander Residents in New Zealand. In Coles, T. and Timothy, D. J. (eds) Tourism, Diasporas and Space. London. Routledge: 78-94.

IOANNIDES, D. and IOANNIDES, M.C. (2004). Jewish Past as a 'Foreign Country' - The Travel Experiences of American Jews. In Coles, T. and Timothy, D. J. (eds) Tourism, Diasporas and Space. London. Routledge: 95-110.

JACKSON, R. T. (1990). VFR Tourism: Is it Underestimated? Journal of Tourism Studies 1(2): 10-17.

LEHTO, X. Y., MORRISON, A. M. and O'LEARY, J. T. (2001). Does the Visiting Friends and Relatives' Typology Make a Difference? A Study of the International VFR Market to the United States. Journal of Travel Research 40(Nov): 201-212.

MORRISON, A. M. and O'LEARY, J. T. (1995). The VFR Market: Desperately Seeking Respect. Journal of Tourism Studies 6(1): 2-5.

MOSCARDO, G., PEARCE, P. L., MORRISON, A., GREEN, D. and O'LEARY, J. T. (2000). Developing a Typology for Understanding Visiting Friends and Relative Markets. Journal of Travel Research 38: 251-259.

RYAN, C. and TRAUER, B. (2005). Ageing Populations - Trends and the Emergence of the Nomad Tourist. In Theobald, W. (ed) Global Tourism (Third edition). Oxford. Butterworth Heinemann: 510-528.

SEATON, A. V. (1994). Are Relatives Friends? Reassessing the VFR Category in Segmenting Tourism Markets. In Seaton, A.V., Jenkins, C. L., Wood, R.C., Dieke, P.U.C., Bennett, M. M., MacLellan, L. R., and Smith, R. (eds) Tourism - The State of the Art. Chichester. Wiley: $316-321$.

SEATON, A.V. and PALMER, C. (1997). Understanding VFR Tourism Behaviour: The First Five Years of the United Kingdom Tourism Survey. Tourism Management 18(6): 345-355. 
Visiting Friends and Relatives - the Case of Hamilton: T. Lockyer and C. Ryan

SEATON, A.V. and TAGG, S. (1995). Disaggregating Friends and Relatives in VFR Tourism Research: the Northern Ireland Evidence $1991-1993$. Journal of Tourism Studies 6(1): 6-18.

TURNER, L. W. and WITT, S. F. (2001). Factors Influencing Demand for International Tourism: Tourism Demand Analysis Using Structural Equation Modeling Revisited. Tourism Economics 7(1): 21-38.

Submitted: May 3, 2005

Accepted: December 12, 2005 